\title{
Michel Brix, Chronologie de la vie et des œuvres de Gérard de Nerval
}

\section{Lise Sabourin}

\section{(2) OpenEdition}

10 Journals

\section{Édition électronique}

URL : https://journals.openedition.org/studifrancesi/21466

DOI : 10.4000/studifrancesi.21466

ISSN : 2421-5856

Éditeur

Rosenberg \& Sellier

\section{Édition imprimée}

Date de publication : 1 décembre 2019

Pagination : 591

ISSN : 0039-2944

\section{Référence électronique}

Lise Sabourin, « Michel Brix, Chronologie de la vie et des œuvres de Gérard de Nerval », Studi Francesi [En ligne], 189 (LXIII | III) | 2019, mis en ligne le 01 mars 2020, consulté le 11 novembre 2021. URL : http:// journals.openedition.org/studifrancesi/21466; DOI : https://doi.org/10.4000/studifrancesi.21466

Ce document a été généré automatiquement le 11 novembre 2021.

\section{(c) (i) (9)}

Studi Francesi è distribuita con Licenza Creative Commons Attribuzione - Non commerciale - Non opere derivate 4.0 Internazionale. 


\title{
Michel Brix, Chronologie de la vie et des œuvres de Gérard de Nerval
}

\author{
Lise Sabourin
}

\section{RÉFÉRENCE}

Michel Brix, Chronologie de la vie et des œuvres de Gérard de Nerval, Tusson, Du Lérot éditeur, 2017, 479 pp.

1 Le grand spécialiste de Nerval qu'est Michel Brix accomplit avec cet important volume un projet auquel l'ont initié Jean Guillaume et Claude Pichois en effectuant en 1984 une enquête identique pour les années 1850-1852: publier une chronologie aussi fine et détaillée que possible des faits liés à la vie et aux œuvres du poète, romancier, dramaturge, voyageur et conteur. Maniant en expert les travaux antérieurs - édition des Euvres complètes en «Pléiade» (1984-1993), son Nerval journaliste (1986), son Manuel bibliographique (1997) et le Dictionnaire Nerval écrit avec Claude Pichois (2006) - Michel Brix les mentionne sans reproduire leurs notices, s'attachant à développer au contraire les témoignages plus récemment mis à jour.

2 Ainsi tous les nervaliens disposent-ils désormais d'un instrument précieux, muni d'index nominum ainsi que des œuvres et projets de Nerval, qui constitue une véritable somme de savoir comme trop peu d'universitaires entreprennent actuellement d'en procurer. Il y faut, il est vrai, le temps de toute une vie de recherche et le dévouement de s'y adonner sans privilégier son propre discours, mais de se mettre au service d'un grand auteur et de tous ses lecteurs. Nous ne saurions trop féliciter non plus les éditions du Lérot de publier cette entreprise, a priori peu vendeuse, mais promise à entrer dans toutes les grandes bibliothèques par sa portée d'ouvrage de référence. 